\title{
A brief history of the Tatar language teaching in universities in the 1920s and 1930s
}

\author{
Gulnara Kalganova $^{1 \mathrm{a}}$, Zoya Kirillova ${ }^{2}$ \\ ${ }^{1}$ Department of Foreign Languages, IME\&F, Kazan Federal University, Russia \\ ${ }^{2}$ Department of General Linguistics and Turkish Studies, IP\&IC, Kazan Federal University Russia
}

\begin{abstract}
This paper investigates the history of the Tatar language functioning in the Tatar Republic which was created in 1920 as the Tatar Autonomous Soviet Socialist Republic. Since 1921, the republic began to grant Tatar the status of the state language which was used in almost all spheres of public life. In our article the main attention is paid to functioning of the Tatar language in the higher educational institutions of the Tatar republic in the 1920s and 1930s. To this end, archival documents and published materials were analyzed; main universities of the republic were reviewed; statistics on the number of Tatar students were given; use the Tatar language in these universities and main teaching methods implemented were explored; the textbooks on the Tatar language were described; some difficulties in the Tatar language teaching in the period under review were pointed out.
\end{abstract}

Keywords: the Tatar language, higher educational establishments, language teaching, the Tatar Republic, state language, 1920s and 1930s.

\section{Introduction}

In the 1920s, the process of declaring the language of a titular nation as a state language was widespread in all the republics and regions of Russia, and the Tatar republic did not stay on the sidelines. A year after the formation of the Tatar Autonomous Soviet Socialist Republic, the Tatar language was declared a state language along with Russian. As a result, in the 20-30s of the XX century, the Tatar republic actively pursued the process of implementing the Tatar language as a state language. This process was started on June 25, 1921, i.e. The Decree proclaiming the Tatar language for the first time in history the official state language on a par with Russian [18, p.5-6] was signed by the first anniversary of the formation of the TASSR. It is a fact that the Tatar language, rich in ancient literary traditions, played the role of the second state language in the XVII-XVIII centuries and in the first half of the XIX century in Russia's domestic policy and in diplomatic relations with the countries of the East. It was taught not only in Kazan, but also in the educational institutions of many Russian cities.

\footnotetext{
${ }^{a}$ Corresponding author: gkalganova@yandex.ru
} 


\section{Methods}

In our work we used the methods as follows: the method of document analysis, the descriptive method, the method of observation, the comparative method, etc. The materials of the National Archives of the Republic of Tatarstan (NA RT), published scientific and periodical literature, and the decrees of the period under review were studied.

\section{Findings}

\subsection{Realization of the Tatar language in Education}

In the first years after the proclamation of the Tatar language as a state one the work was going through great difficulties. The implementation of the Decree's resolutions was hampered by the shortage of qualified Tatars who knew Tatar and Russian languages equally well, the small number of Tatar employees working in state institutions, the small number of Tatar teachers with higher education, the shortage of textbooks, teaching aids and programs for teaching the Tatar language, the terrible famine of 1921 and its consequences. However, from the middle of 1922 decrees and resolutions on the Realization of the Tatar Language (RTL) not only in state institutions, but also in cooperatives, trade unions, cantons, volosts and village councils began to be issued. After that, a big campaign to introduce the Tatar language into all spheres of public life in the republic was launched [6, p.996], [3, p.337].

In the first document of 1921 on the implementation of the Tatar language as a state language the teaching of the national language of the indigenous population was determined only for those who wished. However, on the basis of the instruction adopted on December 21, 1922, for all students at all second-level schools (seven- or nine-year-old ones), vocational schools, party schools, workers' faculties and universities, and also in the last grades of the first-level schools in cities the Tatar language studying became compulsory $[2, \mathrm{p} .6,13]$.

Work of vocational and technical educational institutions, courses, schools of FZU (factory apprenticeship), technical schools, workers' faculties and universities was supervised by the General Directorate of Vocational Education, abbreviated as Glavprofobr.

In the 1920s, the Tatar republic had only five universities and lagged far behind the center of Russia, for example, by the mid-1920s 28 universities operated in Moscow and 24 universities in Leningrad (now St. Petersburg) [10, p.107]. From the universities of the Tatar republic, which were all located in the capital of Kazan, only the Kazan State University and the Kazan Veterinary Institute were old educational institutions; KSU was opened in 1804, and the Veterinary Institute has been working since 1874. The Eastern Pedagogical Institute, the Kazan Institute of Agriculture and Forestry, and the Tatar Communist University were formed only after the revolution, mainly in 1922 [10, p.111112].

During the 1920s there was a noticeable shift in attracting Tatars to these educational institutions. For example, in the period of 1922-1931 the number of Tatars studied in universities increased by $18.8 \%$. This was confirmed by some statistical data on the number of Tatar students in the republic: 1922/1923 - 5.17\%; 1923/1924 - 9.7\%; 1924/1925 $11.7 \%$; 1925/1926 - 14\% [26, p.146-147]; 1926/1927 - 8.2\%; 1927/1928 - 9.8\% [16, p.1516]; 1929/1930 - 20.1\%; 1930/1931 - 24\% [17, p.280]. Among the universities, a small number of Tatar students studied at the Kazan Veterinary Institute and Kazan State University. For example, in 1925-1927 in the Veterinary institute Tatars made 3.7-3.8\%, 
and at the Kazan University - 6.7-7.03\% [26, p.147]. To facilitate the entry of Tatars into educational institutions some preparatory courses and groups were formed. But, unfortunately, those years, even in those educational institutions where the majority of students were Tatars, the training was conducted in Russian.

It might be noted that, based on numerous decrees of the Tatar Republic, instruction in the Tatar language in higher educational institutions became compulsory. It is clear from documents that students were required to pass examinations in Tatar, otherwise they did not receive diplomas. There was a postscript as follows: if in exceptional cases graduation diplomas were still awarded, there the absence of a test in the Tatar language was indicated [13, p.229].

But in fact, this instruction was fully realized only in the Eastern Pedagogical Institute [11, p.38], while in other educational institutions instruction in the Tatar language was not either introduced at all or the Tatar language was taught only for those who wished. There wasn't a special program for teaching the Tatar language to Russian-speaking students that complicated the matter as well. Considering that it was still too early to create a special program for universities, the members of the Methodological and Pedagogical Commissions at the Academic Center offered temporarily to take the programs written for the 2nd level (nine years) Russian schools as a basis for higher schools [12, p.12-13].

Since 1919, the State Worker's Faculty at KSU expanded its activities, and a special working department at the Eastern Pedagogical Institute made the same since 1923. To be admitted to the State Worker's Faculty, the Tatars had to go through preparatory groups, because their knowledge was not enough not only for studying at universities, where the training was conducted in Russian, but also for admission to the working faculties [5, p.90].

As can be seen from the archival sources, the General Directorate of Vocational Education did not pay adequate attention to the problems of the Tatar language teaching in its subordinate educational institutions. Except for one document, which stated that within two years the Tatar language was studied 2 hours a week, and there were no other regulations $[15, \mathrm{p} .8]$.

In 1925, a resolution on the training of teachers for non-Russian schools was adopted by the Council of People's Commissars of the RSFSR, and, in accordance with it, several universities and pedagogical institutes organized national divisions (for example, the Mari, Udmurt, and Chuvash ones were opened at the Kazan Pedagogical Institute). Creation of the textbooks in national languages was launched. Since 1921, in the Tatar Republic this work, which was done by more than a hundred educators-scientists, linguists, teachers, textbook authors, began to be supervised by the Academic Center under the People's Commissariat of Education of the Republic of Tatarstan [4, p.310].

In the 1920-30s, much attention was paid to textbooks on the Tatar language and literature and school textbooks on the Russian language for Tatar schools. During these years, famous teachers M. Kurbangaliev, R. Gazizov, H. Badigi, Z. Badigullin, Z. Badamshin, M. Galeev, and others worked on the creation of the Tatar language textbooks for Russians. Compilation of the Tatar language minimums for Tatar and non-Tartar students began by the universities' Tatar language departments which were opened up until the 1930s [1, p.148]. Textbooks for different specialties as well as numerous terminological dictionaries for various areas were written. For example, prior to 1927, 15 thousand Tatar terms which formed the basis for terminological dictionaries were created [4, p.310].

During these years, two main methods in teaching the Tatar language to other nationalities were identified: translation-grammatical and natural methods. When teaching by the first method, the words of the native language were the necessary means to study a new language. And the starting point of the natural method was a real object, in the absence of which it was proposed to use pictures or models of these objects, in other words, apply some visual means of teaching. The author of numerous textbooks and programs, a prominent teacher and methodologist M.Kh. Kurbangaliev did not recommend using purely 
grammatical or only natural methods in teaching. "Taking as a basis the natural method," he wrote, "it is necessary to apply the method of translation and grammar" [9, p.3-4].

In 1934, M.Kh. Kurbangaliev published a special textbook on the Tatar language for non-Tartar students studying in technical and workers' schools, at universities and technical colleges. The author paid special attention to the comparative study of the common elements of both the Tatar and Russian languages, as well as the features of the Tatar language in comparison with the forms and phrases of Russian speech [8]. To the above, we should add that M.Kh. Kurbangaliev and R.S. Gazizov published a special textbook on the comparative grammar of the Tatar and Russian languages which was actively used in the Tatar language classes [7].

\subsection{The Tatar language teaching at HEls}

From the history of the Tatar language teaching at HEIs, we would like to consider Kazan Financial and Economic Institute (KFEI) as an example. It was founded in 1930 on the basis of the economic faculty of Kazan State University, so the main academic teaching staff was formed from the university's professors. The teaching of the Tatar language was conducted since the founding of the Institute. The department which was responsible for the language training in different years was called in various ways: in 1931 - the Department of the Tatar language and literature; from January 1932 to 1935 - the Department of Languages; from 1935 to 1946 - Methodical Bureau and language cabinet; from 1946 to 2012 - the Department of Foreign Languages.

In the 1930s, according to "indigenization" (or "korenization") (this term defined the policy of the Tatar language specialists' training and using of local languages in the official structures) the institute put forward the following positions:

1) organization of the indigenous groups with teaching in Tatar;

2) scientific staff training from the "nationals" (i.e. Tatars or other nationalities);

3) organization of a commission for terminology development, as well as the compilation and translation of textbooks on various specialties into the Tatar language;

4) teaching the Tatar language for non-Tatars;

5) reorientation of the Tatar language study into financial and economic field.

According to archival documents, in 1931, several indigenous groups were created (i.e., homogeneous in national composition): 4 - at the full-time department, 3 - at the workers' faculty and one group for Chuvashes. In subsequent years the numbers of groups varied. In these indigenous groups the teaching of all disciplines was envisaged in the Tatar language. By the end of 1931, textbooks on statistics, financial science and accounting were already prepared in the Tatar language [13, p.40].

Moreover, in the same year, a terminological commission headed by professor M.Kh. Kurbangaliev was created that, in turn, included the departments' brigades and worked on the development of Tatar terms for various specialties. In particular, in 1932, more than 500 and 700 terms in dialectical materialism and political economy were developed accordingly [24, p.14-16]. Archival documents testify to the work of the terminological commission for the Chuvash language, but that work was not completed [21]. The following textbooks on various subjects that were compiled or translated into Tatar can be identified: "USSR Finance", "Statistics", "Economic Geography of the USSR", "Political Economic Geography of the Capitalist World", "Accounting"; "Economics and Finance of Industry", "Mathematics" were read in Tatar [25, p.37]. Since there was a shortage of relevant literature and lecturers who knew the Tatar language, the system of instruction in indigenous groups looked as follows: lectures were read in Russian with reference to literature in Russian, but consultations were conducted in Tatar with translation of 
assignments into Tatar; maps and visual aids were also drawn in the Tatar language. By the 3rd semester the training was planned to be fully translated into Russian [24, p.14].

At that time the professionalising of the Tatar language study had a practical application. Due to predominance of the Tatar population in rural areas, the business and every day communication in the regions distant from Kazan was in Tatar. Therefore, during the students' practice it was recommended to include in their work some elements of Tatar speech activity, namely, practice in live speech, collection of terms, familiarity with samples of business papers, etc.

The Methodological bureau of languages was engaged in promoting various languages. For example, the plans on extracurricular activities for the 1936-1937 academic year included the following activities:

- issuing posters in any foreign language;

- arranging literary circles on Russian and Tatar literature;

- arranging literary evenings in foreign languages;

- setting up groups of German and English studying for the Institute's scientists;

- providing a series of lectures on literature in Russian and Tatar;

- setting up of advisory board in German, English, French, Russian and Tatar languages

$[19$, p.3].

The language cabinet received literature in 13 languages: in foreign languages, Russian, Tatar, Bashkir, Chuvash, Mari, Crimean-Tatar and other languages [20, p.35].

Concerning methods of languages teaching there is quite interesting information. In relation to native languages, a brigade-laboratory method that was popular in the 1930s was used, and in comparison to non-native (foreign) languages - combined one that conjoining elements of brigade-laboratory and classroom methods (speaking, reading aloud, translating, "continuous" exercises in grammar and syntax). The brigade form of training included initially individual work and afterwards working out the material in brigades for 56 people [24, p.35].

In the archival documents, since 1939, the Tatar language teaching in the KFEI was not mentioned. In the same year, as it is known, the Tatar language was translated into Cyrillic, and the policy of "korenization" and "tatarization" was curtailed.

In the 1930s, in other Kazan universities the similar situation was observed: providing the "indigenous" policy of the university to any extent, the development of scientific terminology, and the lack of educational literature. For example, at the Kazan State University, the Tatar language for Tatars was taught at the following faculties: geography, physics and mathematics, biology, and chemistry [22]. Until 1939, in the Kazan Institute of Chemical Technology named after S.M. Kirov the Tatar language was taught optionally only for Tatar students. In particular, the report of the Department of Languages for the academic year of 1934-1935 drew attention to the activities of various circles: for the elimination of illiteracy, literary, and translation ones [23].

\section{Conclusion}

Despite the numerous difficulties, by the end of the 1930s, full-fledged functioning of the Tatar language could already be provided by staff of Tatars trained at the universities of the Tatar republic for working in different fields. For example, in 1936, the number of Tatars working in central organizations and commissariats amounted to $38.5 \%$, and among the leaders the number of Tatars reached even $47.4 \%$ [6, p.998].

Summing up the given research, it is possible to come to conclusion that in the Tatar republic during the 1920s-1930s a lot of work on the application of the Tatar language in various fields was done, including attracting Tatars to higher educational institutions and the Tatar language teaching at the republic's HEIs. 


\section{References}

1. Bayramova L.K. Tatarstan: language symmetry and asymmetry. Kazan: Kazan University Publishing House, 267 (2001).

2. Collection of the decisions, regulations, most important circulars and other important materials in the field of the implementation of the Tatar Autonomous Soviet Socialist Republic. Kazan: Publishing center of the Commission for the implementation of the Tatar language under the central executive committee of the Tatar Autonomous Soviet Socialist Republic, 88 (1925).

3. Kirillova Z.N., Kalganova G.F. Activities of the Tatar Studies' Scientific Society. International Multidisciplinary Scientific Conferences on Social Sciences and Arts SGEM, 2, Albena (Bulgaria), 335-340 (2016).

4. Kirillova Z.N. Tatar Education from 1920-1930. The European Proceedings of Social \& Behavioral Sciences EpSBS, IFTE, 12. Kazan: The Future Academy, 307-312 (2016).

5. Kirillova Z.N. The Tatar language as a state language (20-30 years). Kazan: Master Line, 208 (2000).

6. Kirillova Z.N. The Tatar language realization as the official (20s-30s of the XXth century). International Multidisciplinary Scientific Conferences on Social Sciences and Arts, SGEM, 3, Albena (Bulgaria), 995-1001 (2014).

7. Korbangaliev M., Gazizov R. Systematic grammar of the Tatar language in comparison with Russian grammar. Kazan: Tatizdat, 171 (1932).

8. Korbangaliev M. The Tatar language textbook for non-Tatars. Kazan: Tatgosizdat, 252 (1934).

9. Korbangaliev M., Gazizov R. The Tatar language textbook for the Russians. For the 5th grade of the 2nd level schools, 177 (1930).

10. Over 5 years. For the 5 th anniversary of the proclamation of the Tatar Soviet Socialist Republic. Kazan, 208 (1925).

11. Report of the Central Commission on the implementation of the Tatar language under the CEC Tat.ASSR "On the situation of the RTL and perspectives" at the 3rd Session of the Central Executive Committee of the Tatar SSR on 12-13 March 1927 (Transcript). The debate and the report's resolution. Kazan: Central Committee of the RTL under the TCEC, 68 (1927).

12. The Tatar language programme for the 2nd level (9 years) of Russian schools and higher education establishments. Kazan: The People's Commissariat edition, 33 (1927).

13. Documents of the Kazan financial and economic institution's establishing, 1931. NA RT. F.R-7351. Op.1. D.1, 42 (in Russian, unpublished).

14. Materials on activity of the Central Committee on RTL (1 October 1925 - 30 September 1926). NA RT. F. R-732. Op.1. D.768, 297 (in Russian, unpublished).

15. Materials on activity of the Central Committee on RTL ( $1-30$ October 1926). NA RT. F. R-732. Op.1. D.769, 235 (in Russian, unpublished).

16. Materials on indigenization of the soviet administration and RTL in the republic in 1927 (1 January - 1 December 1927). NA RT. F. R-732. Op.1. D. 1138, 126 (in Russian, unpublished).

17. Materials on republic's agriculture state, administration's indigenization and RTL, etc. (6 June 1929 - 5 November 1930). NA RT. F.R-732. Op.1. D.1307, 429 (in Russian, unpublished).

18. Minutes of the CEC of the TSSR's general committee (1 October - 6 December 1921). NA RT. F.R-732. Op.1. D.49, 103 (in Russian, unpublished), (1921)

19. Minutes of the meetings, annual and semestrial plans and reports of the institute's language bureau. NA RT. F. R-351. Op.1. D.54, 56 (in Russian, unpublished). 
20. Minutes of the meetings, semestrial and language bureau reports of the first semester of the 1937-1938 academic year. NA RT. F. R-7351. Op.1. D.135, 35 (in Russian, unpublished).

21. Minutes of the terminology commission's meetings, 1933. NA RT. F. R-7351. Op.1. D. 26, 45 (in Russian, unpublished).

22. Reports of the department and observatory's activity for the 1932-1933 academic year. NA RT. F. R-1337. Op.32. D.57, 30 (in Russian, unpublished).

23. Report of the language department for the 2nd semester of the 1934-1935 academic year. NA RT. F. R-2647. Op.2. D.35, 5 (in Russian, unpublished).

24. Reports on the state of the Institute's teaching methods during the 1931-32 academic year. NA RT. F. R-7351. Op.1. D.13, 64 (in Russian, unpublished).

25. Semestrial plans and reports on departments' activity for the 1931-1932 academic year. NA RT. F. R-7351. Op.1. D.12, 60 (in Russian, unpublished).

26. Statistics data on ethnic composition of the republic's central and jurisdictional organizations. List of cantons commissions' members on RTL (1 October $1925-30$ September 1926). NA RT. F. R-732. Op.1. D. 766, 204 (in Russian, unpublished). 